\title{
A ESCRITA DE SI COMO CONTEXTO FORMATIVO DE UMA PROFESSORA NA CONSTRUÇÃO DE SUA IDENTIDADE PROFESSORAL
}

\author{
Edvone da Silva Souza ${ }^{1}$, Jose Aurimar dos Santos Angelim² \\ ${ }^{1}$ Graduada em Pedagogia pela Universidade do Estado da Bahia - UNEB. Professora regente da Prefeitura Municipal de \\ Senhor do Bonfim. Gestora da Cooperativa de Ensino de Senhor do Bonfim - Escola Nova Geração. \\ ${ }^{2}$ Doutor em Educação Matemática pelo Instituto de Educação Matemática e Científica - IEMCI da Universidade Federal \\ do Pará - UFPA. Professor do Instituto Federal de Educação, Ciência e Tecnologia Baiano, Campus de Senhor do \\ Bonfim. Parceiro da Universidade do Estado da Bahia - UNEB, Campus Senhor do Bonfim, atuando em colaboração \\ com o NEMAT - Núcleo de Educação Matemática.
}

\section{RESUMO}

Esse artigo é produto de uma pesquisa autobiográfica, buscando tecer reflexões teóricas, embasadas nas escritas de si, de docentes que são alunos de um curso de especialização em educação de jovens e adultos, buscando, a partir de suas narrativas, investigar em que termos as memórias das experiências formativas de docência destes alunos/professores manifestam a autoformação como formação. Lançamos mão dessa abordagem por entendermos que as histórias de vida e formação apresentam um estudo construído a partir dos acontecimentos, eventos, saberes, conhecimentos, atitudes e sentimentos, que emergem de uma prática docente diferenciada, quando se trabalha na perspectiva da educação de jovens e adultos. Para a construção dessa narrativa, nos apoiamos na possibilidade da triangulação de dados, utilizando do diário de bordo, questionários e entrevistas, buscando construir uma pesquisa sólida. Como indícios das falas dos sujeitos, visualizamos que a opção pelo magistério já estava consolidada na trajetória de vida de muitos dos sujeitos pesquisados, comprovada pelo sentimento de alteridade, o que permite aos sujeitos compreenderem e reforçarem teorias como a de Nóvoa (1995), Schön (2000), Tardif (2002) e Freire (2006), que buscam caracterizar um profissional da educação mais voltado aos valores humanos.

Palavras-chave: Escrita de Si. Memórias. Experiência. Formação e Desenvolvimento profissional. Identidade.

\section{THE WRITING OF SELF AS THE FORMATIVE CONTEXT OF A TEACHER IN THE CONSTRUCTION OF HIS PROFESSORIAL IDENTITY}

\begin{abstract}
This article is the product an autobiographical research, seeking to weave theoretical reflections, based on the writings of self, of teachers who are students of a specialization course in youth and adult education, searching, from their narratives, to investigate in what terms the memories of the experiences of teaching of these students / teachers manifest self-formation as training. We use this approach because we understand that life and training stories present a study based on the events, events, knowledge, attitudes and feelings that emerge from a differentiated teaching practice, when adults. For the construction of this narrative, we rely on the possibility of triangulation of data, using the logbook, questionnaires and interviews, seeking to build a solid research. As evidence of the subjects' speeches, we visualized that the option for teaching was already consolidated in the life trajectory of many of the subjects surveyed, confirmed by the feeling of alterity, which allows the subjects to understand and reinforce theories such as Nóvoa (1995), Schön (2000), Tardif (2002) and Freire (2006), who seek to characterize a professional education more focused on human values.
\end{abstract}

Keywords: Writing of Yes; Memories; Experiences; Formation and professional development; Identity. 


\section{À GUISA INTRODUTIVA NO CONTEXTO DA ESCRITA DE SI}

A perspectiva de construção de uma vida profissional, com ênfase no processo de desenvolvimento profissional, perpassa, em especial, quando se trata da docência cotidiana, por contextos fortemente caracterizados a partir de elementos subjetivos, que influenciam diretamente na constituição da identidade docente.

Escrever sobre meu percurso constitutivo docente, apoiando-me nas memórias/recordações experienciadas, atreladas à necessária construção de um olhar frente à identidade professoral a qual me propus desde a formação inicial em Magistério, me sugere compreender a relevância do uso da Pesquisa Narrativa (CLANDININ; CONNELY, 2011), uma vez que essas memórias/recordações geram narrativas que sustentam seu uso enquanto método por ser "uma forma de entender a experiência", e, no caso deste artigo, caracteriza a escrita de si como meio para a construção da identidade profissional docente.

Apropriar-me da Pesquisa Narrativa, me leva a rememorar as experiências como potencialidades do vivido, em âmbitos diferenciados, mas convergentes, numa direção para o reconhecimento de um percurso formativo docente (que se faz constante). No entanto, esse percurso me leva à compreensão de que,

Contar é muito dificultoso. Não pelos anos que já se passaram. Mas pela astúcia que tem certas coisas passadas de fazer balancê, de se remexerem dos lugares. A lembrança da vida da gente se guarda em trechos diversos; uns com os outros acho que nem se misturam. Contar seguido, alinhavado, só mesmo sendo coisa de rasa importância [...] Tem horas antigas que ficaram muito mais perto da gente do que outras de recente data. O senhor sabe; e se sabe me entende. Toda saudade é uma espécie de velhice. (ROSA, 2003, p. 7) e, dele me encaminhando para a compreensão de mim mesmo, vislumbro que "trago dentro do meu coração, como num cofre que não se pode fechar de cheio" (PESSOA, 1980, p.238) as marcas de tantas histórias contadas de minha vida, ao ponto de retornar aos 13 dias do mês de setembro de 1971, na Fazenda Pedra Vermelha, município de Jaguarari, Bahia, quando em meio a grande expectativa, nasce uma criança muito esperada, com seu belo enxoval azul, confirmando o desejo da chegada de um menino. Contudo, a parteira deu a notícia de que mais uma vez, uma bela menina chegava, e já se caracterizava como a irmã do meio das três mulheres que nasciam na família Borges.

$\mathrm{E}$, impreterivelmente, no contexto da escrita desse artigo, ecoa em mim consideravelmente, um processo de constituição do eu-sujeito, que relaciona formação pessoal e profissional, produzindo um momento charneira ${ }^{1}$, onde se vê a história por um ângulo que foi formado no decorrer de todo o percurso vivido pela atriz-autora e que deixou marcas formadoras, que reverberam no desenvolvimento profissional da professora que sou.

Dentre as experiências que julguei mais significativas, situo a maior dor ora já vivenciada na esfera da minha história de vida: a morte de meu amor maior - meu pai. Como separar este momento tão real, decisivo no meu caminhar, desse momento de formação que ora me encontro, se contar é muito dificultoso?! "A lembrança da vida da gente se guarda em trechos diversos, uns com os outros, acho que nem se misturam" (ROSA, 2003, p. 7). Entretanto, a partir da escrita de si, tomo os momentos da trajetória formativa que compõem o percurso, defendendo minha percepção de identidade professoral como um processo de autoformação ${ }^{2}$.

Ao estudar sobre a escrita de si e das narrativas de vida que se manifestam como autoformação, encontro um caminho sugestivo, pois quando falo de mim e de minha história de vida e formação, remeto-me a cada momento em que sonhei, acreditei, busquei e, transformei momentos difíceis em possibilidades. Assim,

\footnotetext{
${ }^{1}$ Charneira segundo Josso (2010) é uma passagem entre duas etapas de vida, um divisor de águas. São acontecimentos que separam, dividem e articulam as etapas da vida.

${ }^{2}$ A ideia de autoformação é aqui entendida como a possibilidade do/a educador/a intervir em sua formação de maneira sistemática a partir de seu desejo de qualificação, da consideração de suas demandas específicas e de sua indispensável participação e comprometimento (LEITÃO, 2000, p. 1).
} 
fortalece-se, nessas narrativas autobiográficas, "o que nos passa, o que nos acontece, o que nos toca", e, "a cada dia se passam muitas coisas, porém, ao mesmo tempo, quase nada nos acontece" (LARROSA, 2002, p. 22), logo, compreendo que a experiência, textualizada a partir das memórias traz vida à pesquisa e à formação docente, forma e transforma os sujeitos, pois:

Nessa situação confluem sentidos e constelações de sentidos vindos, tal qual rios, das nascentes das nossas práticas locais e arrastando consigo as areias dos nossos percursos moleculares, individuais, comunitários, sociais e planetários. Não se trata de um amálgama de sentido (que não seria sentido mas ruído), mas antes de interações e de intertextualidades organizadas em torno de projetos locais de conhecimento indiviso." (SANTOS, 1997, p. 45).

Então, essa confluência de sentidos, percepções, saberes e fazeres, constituídos no chão da escola, a partir da inserção no mundo da Educação de Jovens e Adultos, no turno noturno, me constituíram em um sujeito plural e, certa de que, diante das marcas de tantas histórias contadas da minha vida e da vida de outras pessoas, há um oscilação quanto ao que vale, quanto a quem sou e para onde vou, o que me faz certificar que "é impossível separar o eu profissional do eu pessoal" (LABORIT, 1992, p. 55), ou seja, é possível compreender que "a história de vida é outra maneira de considerar a educação. Já não se trata de aproximar a educação da vida, como na perspectiva da educação nova ou da pedagogia ativa, mas de considerar a vida como o espaço de formação." (DOMINICÉ, 1988, p. 140).

É relevante afirmar que as narrativas que construo, tomando minhas memórias/recordações, me constituem como sujeito, cujo sentido sobre o que sou, faculta a dependência das histórias que conto e que também me foram contadas, em particular, daquelas construções em que, assumo o papel de autora, narradora e personagem principal.
Nesse sentido, as experiências - aquilo que me toca - tornam-se formativas, constituem o sentido da existência e concepção do que sou, quando retorno a elas, textualizando-as, seja oralmente, na troca de experiências com o outro que me constitui cotidianamente (em reuniões entre os pares na escola, em reuniões informais em envolvimento com associações, em momento de atividade profissional de gestão, em encontros familiares, etc), ou por escrito por meio de narrativas autobiográficas, de produções de diários $^{3}$ de campo, de produções científicas, de pesquisa e extensão, por exemplo. Afirmo que, através das narrativas realizo um encontro comigo mesma, no caminhar para essa constituição e desenvolvimento profissional docente.

Diante do exposto, sinto que o diálogo (metafísico, memorial ou até mesmo consciencial) entre meu pai e eu, é forte, real e intenso, o que me leva a reconhecer e, consequentemente, afirmar que nos constituímos através do outro (VYGOTSKY, 1991). Diante das minhas alegrias, conquistas e dificuldades, suas lições de vida [de meu pai], sua presença risonha e amável, direcionam os momentos mais importantes da minha vida. Seus ensinamentos me oportunizam a me tornar gente mais gente, e me leva a caminhar retirando as pedras que se apresentam como obstáculos, talvez epistemológicos ${ }^{4}$, favorecendo minha auto constituição.

O exercício da produção das narrativas acerca de minhas memórias/recordações me faz ver, que nesse caminhar em que oscilo quanto ao que vale, quem sou, para onde vou, certifico-me que

Os percursos da
construção da cultura
profissional são múltiplos.
Tão múltiplos quanto os
percursos da formação
humana. Um permanente

\footnotetext{
${ }^{3}$ Corroboramos com Clandinin e Connely (2011, p. 145), quando nos afirma que diários são um meio poderoso para que as pessoas possam dar relatos de suas experiências(...)Diários são um método de criação de textos de campo.

${ }^{4}$ Para mim, lidar com a perspectiva das pedras do meu caminho é reconhecer, também, que essas pedras figuram-se como obstáculos na definição de Gaston Bachelard. Segundo a epistemologia bachelardiana, o conhecimento científico progride mediante rupturas epistemológicas sucessivas. Porém esse processo é marcado por algumas dificuldades ou "entraves", denominados por Bachelard (1996) de obstáculos epistemológicos. Dentre os citados, aqui nesse texto, compreendo que as pedras podem se configurar como "a primeira experiência" e também como "o obstáculo generalista".
} 
tecido de muitos fios. Uma permanente escuta e interrogação de vivências e sentimentos. De uma greve, de um encontro, de uma oficina ou reunião pedagógica, e um livro ou de um mestre não aproveitamos apenas consciência, ilustração, lições, mas as respostas que dão às nossas perguntas mais existenciais. Aproveitamos o quanto nestes encontros, lições e trocas, nos matemos abertos à capacidade de interrogarnos acerca do que somos como humanos. (ARROYO, 2011, p. 201-202).

Sinto que a mão que toca o teclado do computador já não fala só por mim (há muito que não falo só por mim). São os outros que falam comigo neste momento em que tento narrar minha trajetória pessoal e profissional, visualizando os elementos de alegria e tristeza como alicerces também de uma construção profissional.

Ao destacar que meu momento de formação está em contínuo processo, corroboro com Chaves (2013, p. 218) ao afirmar que "não é, portanto, o olho que nos faz dizer o que vemos, mas o que é dito, repetido e reeditado continuamente que nos faz ver de determinado modo". Não obstante, vamos construindo e reconstruindo nossas histórias para confirmar nosso processo de busca pelo inacabado, na intenção de podermos, um dia, fazer com que se entenda que todo e qualquer registro é autoformativo e configura-se como autoconhecimento.

As possibilidades abertas pelo resgate da memória de minha história de vida me levam a sentir que tudo sobre mim é tão relevante, prazeroso e indispensável. Enquanto docente compreendo que os saberes próprios da docência se constituem como saberes compostos de vários saberes, provenientes de diferentes fontes e construídos em contextos interinstitucionais e profissionais distintos e convergentes.

Enfim, lidar com uma condição investigativa, imersa na pesquisa da minha própria prática e formação, assegura que é como se diante desta oportunidade de escrita da minha voz abafada pudesse trazer à tona todo o sentimento de pertencimento e coautoria de uma história por muito silenciada, configurando a certeza de que mais importante que formar é formar-se; que todo conhecimento é autoconhecimento e que toda formação é autoformação (NÓVOA, 1992).

\section{DO MEU LUGAR DE CONSTITUIÇÃO HUMANA À DOCÊNCIA}

Filha de família do campo, eu crescia no meio rural, onde as riquezas da liberdade conjugada com as dificuldades das oportunidades caminhavam paralelas. Pais semianalfabetos, agricultores e feirantes, davam conta de quatro crianças cuja diferença de idade era de 01(um) ano entre um e outro. Meu pai ajudava muito a minha mãe; carregava água da fonte para casa, buscava a lenha para ela, ajudava na barraca da feira e ainda levava café pela manhã na cama. Ao retomar essas memórias, visualizo que o contar da história dos antepassados indígenas e negros dos livros didáticos de histórias fosse também minha história (e o são!), o que então valida a afirmação de que "existem tensões e dilemas ao estudar o desfile do qual somos parte" (CLANDININ; CONNELY, 2011, p.120).

Aos cinco anos de idade tive os primeiros contatos com o mundo da leitura, tendo como professora minha mãe, que era a professora da comunidade. Mulher definida, dura e determinada, com uma formação de 4ạ série primária, enquanto meu pai, na doçura e paciência que ora lhe compunha, me ensinava a tabuada cantada.

O processo de alfabetização se deu com o uso do $A B C$, onde eu era obrigada a memorizar todas as letras para dar a lição na ordem do alfabeto e de trás para frente e, ainda havia a sabatina com o uso do papel vasado sobre as letras do alfabeto de forma salteada para confirmação de que eu tinha "aprendido" de verdade. É interessante destacar que essa memória confirma que "só uma história de vida põe em evidência o modo como cada pessoa mobiliza seus conhecimentos, seus valores, suas energias, para ir dando forma à sua identidade, num diálogo com os seus contextos" (MOITA, 2013, p. 116).

Meu lugar de escrita desse artigo, dá-se, na condição de participação num processo de formação continuada, onde apoiando-me nas minhas memórias/recordações, bem como em memoriais de professores e professoras colegas, 
atuantes na EJA - Educação de Jovens e Adultos, ao mesmo tempo em que me emociona me leva a certificar de que é na tessitura de uma trama coletiva, cheia de idas e vindas, entrelaçada com as histórias de tantos outros sujeitos, que nos construímos enquanto professores. Nesse processo cheio de idas e vindas, de atalhos e bifurcações os professores e professoras vão se formando, vão tecendo uma "maneira de ser e estar na profissão" (NÓVOA, 1995, P. 17).

Respaldada no contexto apresentado até o momento, me inquieto no intuito de investigar em que termos as minhas memórias das experiências formativas de docência e as memórias contidas nos memoriais dos professores que são alunos do curso de Especialização em Educação de Jovens e Adultos, manifestam a autoformação como formação. Para responder a esta inquietação, lanço mão das escritas de si, minhas e dos outros alunos/professores, com a intenção de construir estruturalmente um texto que apresente estas memórias como elementos investigativos respaldados nas teorias científicas que dialoguem com a perspectiva da autobiografia como produtora de conhecimento acadêmico.

Somos impelidos, com a prática docente cotidiana, a ampliarmos os nossos saberes, gerados na prática e pela prática, para enfrentarmos situações desafiadoras. Esses saberes se inter-relacionam com afetos, emoções, aceitação e repulsa que são responsáveis por momentos guardados na memória de professores/professoras. Momentos que falam de solidariedade, de apoio a iniciativas e descobertas, de autoestima e de cumplicidade. Momentos que falam de segredos carinhosamente divididos, de decisões resultantes de um "papo", de novos caminhos no percurso da vida, fomentado pela palavra amiga, pelo gesto de ternura, pela exigência que soube ser firme (meu orientador) e vestir-se de carinho.

Esses momentos ficam registrados porque são fascinantes ou porque deixam marcas tristes, impregnadas de medo, de desânimo, de perda da autoconfiança, portanto marcas difíceis de serem removidas, mas que carecem de ressignificação, pois "só devassamos o mistério na medida em que o encontramos no cotidiano, graças a uma ótica dialética que vê o cotidiano como impenetrável e o impenetrável como cotidiano" (BENJAMIN, 1994, p. 32).

Grande parte dos profissionais do ensino compreende a convivialidade como um valor essencial e refuta uma concentração exclusiva nas práticas acerca das aprendizagens acadêmicas, dada à condição de que o desenvolvimento profissional ocorre com a imersão no mundo da profissionalização pósuniversidade. No entanto, falar em prática docente, enquanto caminho de identidade no desenvolvimento é afirmar que:

Um ponto de partida mais valioso e menos vulnerável seria observar o trabalho do professor no contexto de sua vida profissional. Muitos dos estudos que emergem nesta matéria indicam que esta incidência permite um fluxo rico em diálogo e dados. Além disso, a incidência pode (e sublinho pode) permitir aos professores maior autoridade e controle da investigação do que no estudo orientado para a prática docente. $O$ que afirmo, aqui e agora, é que particularmente no mundo do desenvolvimento dos professores, o ingrediente principal que vem faltando é a voz do professor. Em primeiro lugar, tem se dado ênfase à prática docente do professor, quase se podendo dizer ao professor enquanto "prático". Necessita-se agora de escutar acima de tudo a pessoa a quem se destina "desenvolvimento". Isto significa que as estratégias a estabelecer devem facilitar, maximizar e, em sentido real surpreender a voz do professor (GOODSON, 2013, p. 69).

Ainda sobre o contexto identitário docente, e considerando as tensões próprias geradas pela necessária vivência da experiência, a escolha pela pesquisa narrativa permite voos bem mais amplos, articulando assim, biografia e história, interligando o singular e o plural, o individual e o social, favorecendo a consolidação de um espaço permeado por diálogos que geram 
informações sobre as tensões reais da prática professoral, sem ter a intenção de identificá-las e/ou nomeá-las, mas proporcionar, com o estreitamento das relações possíveis, o aprendizado de como lidar com essas tensões. Tudo isso gera um macroprocesso de análise, reflexão e reconstrução da experiência (JOSSO, 2014) onde a "compreensão da experiência de formação é a compreensão do eu" (JOSSO, 2010, p. 130).

O uso da prática histórico-reflexiva de minha vida pessoal e profissional e dos memoriais dos colegas professores, no meu diário de bordo, me leva a ratificar a importância que deve ser dada, pelos pesquisadores, em fazerem uso das narrativas autobiográficas e dos diários de campo, uma vez que ao investigar professores em sua prática e formação, é imperioso compreender que eles "além de trazer para a sala de aula a vida pessoal, o momento histórico que vivem (e que vive a sociedade) envolvem-se com os colegas de trabalho, com a vida de seus alunos, com suas dificuldades e com as relações e solicitações efetivas que permeiam a sala de aula" (SCOZ, 2011, p. 109).

Diante dos constantes estudos e pesquisas já realizadas por mim, é notável como a vida do professor ganha uma conotação relevante, aspecto esse, desprezado por muito tempo no quesito da pesquisa cientifica. Ter a leitura dos memoriais formativos como espaço de estudos e análises das experiências de colegas professores e de como essas experiências se confundem com as minhas, contribuiu na ampliação do meu processo de desenvolvimento profissional docente.

Sobre isso, constam nos memoriais, convergências formativas relacionadas ao seio familiar como espaço de experiências, onde, para a grande maioria, há a rememoração das histórias contadas depois do jantar, pelos pais. Há a lembrança da existência de muitas músicas, brincadeiras e a oração antes de dormir, tudo contado e compartilhado pelos pais com os filhos. Portanto, nesses recorrentes momentos eram vivenciados saberes pessoais, basilares para uma percepção, a posteriori, de que "os contos e as histórias de nossa infância são os primeiros elementos de uma aprendizagem que sinalizam que ser humano é também criar as histórias que simbolizam a nossa compreensão das coisas da vida" (JOSSO, 2010 p. 40).

Para mim, a percepção do papel de meus pais, sugere essa condição de ser humano, partindo dos conhecimentos e experiências deles, que coadunam com os griôs ${ }^{5}$, que partilhavam as histórias, oralmente, de geração a geração. Eu os admirava muito por eles bem administrarem a família em todos os âmbitos e ainda organizarem tempo para brincar conosco nas nossas brincadeiras de criança. Em meio a tudo isso, só pensava em ser logo gente grande, afinal a dinâmica da vida professoral me enchia a tela mental com projeções de situações futuras.

A cada acontecimento
presenciado, destacamos
lições diversas que
contribuem com a
formação da vida pessoal
e profissional. É
imprescindivel
compreender a pessoa e
suas experiências, uma vez
que se vive em construção
de saberes de forma
permanente enquanto se
decorre o viver (ANGELIM,
2010, p. 19).

Meu processo de acesso formalizado à escola obedece a uma linha do tempo que tem início aos 6 anos, juntamente com irmãos, primos e outras crianças da zona rural, quando fui matriculada numa escola multisseriada, única escola do povoado, onde estudavam todas as crianças e adultos, nos turnos matutino e noturno, respectivamente. Aos 8 anos fui matriculada em uma outra escola de um outro povoado, cuja professora era esposa do caseiro de uma linda Fazenda, onde funcionava a escola. Era um verdadeiro sonho de consumo! Casa grande, carros, bois, patos, pavões e vários outros animais. Meu pai ia ordenhar as vacas às 5:00 horas da manhã e, me acordava carinhosamente com um toque no "peito" do pé, e a frase: "levanta preguiçosa, já tá na hora de ir à escola".

São memórias como essas que me levam a considerar a importância das autoimagens docentes como processo de inovação diante do ofício de mestre, quando então o contexto rural da educação no campo pode produzir importantes trajetórias onde os saberes da experiência são/estão situados, conforme Pimenta (1999) em dois patamares convergentes: um patamar relacionado ao convívio direto com

\footnotetext{
${ }^{5} \mathrm{O}$ Griô é um guardião da memória e da história oral de um povo ou comunidade, são líderes que têm a missão ancestral de receber e transmitir os ensinamentos das e nas comunidades. Fonte: http://www.cultura.gov.br/category/cultura-e-cidadania/acao-grio/
} 
alunos e futuros professores e os saberes produzidos no contexto ampliado da prática cotidiana docente.

É incrível situar como a vivência experiencial com meu pai me ejetava rumo à vida, recheada de confiança e força de vontade. Para ir à escola, eu pegava carona na garupa da bicicleta dele $e^{6}$. No retorno, a professora me conduzia até metade do caminho e o restante eu soltava o pé na estrada, temendo encontrar alguém desconhecido ou cachorro e assim, eu chegava em casa. Era eu me construindo e formando minha história.

Minha professora me presenteou com um livro de contos e eu não cansava de repetir as leituras, contemplar as imagens, e me permitir a constantes viagens, literalmente. Conhecia outros lugares e conversava com os personagens das histórias com intimidade. Como eu desejava ser aquelas personagens das histórias que eu lia.

Há uma história que sempre ressurge em minhas memórias: a da menina do chapéu cheio de florzinhas coloridas que o vento o levava e os pássaros, que eram seus amigos, traziam de volta. Nesse ponto, passei a ter mais compreensões acerca do que hoje chamam de grupos colaborativos, e o têm na sua mais atuante existência entre os alunos, professores e pesquisadores.

Para além das diversas histórias e contos que me foram apresentados, reverbera em minha prática professoral a certeza de que "o processo de formação acentua um inventário dos recursos experienciais acumulados e das transformações identitárias" (JOSSO, 2010 p. 40), e nos faz reconhecer a certeza do pertencimento de uma macro conjuntura, que associa ensino, aprendizagem e avaliação, como elementos constitutivos do processo de formação docente.

À época, encantava-me a história que envolvia a raposa e as uvas, pois achava a raposa debochada por não conseguir alcançar as uvas, e desprezá-las alegando que não as queria, pois elas estavam verdes, quando na verdade, o ideário apresentado era da não assunção de um pseudo fracasso em torno do objetivo da sobrevivência. No entanto, só anos mais tarde, quando envolvida na formação do Magistério, é que consegui relacionar o desdenho da raposa com os fatos da vida, pois quanto mais

\footnotetext{
${ }^{6}$ Alguns colegas também apontaram situações parecidas, mas não necessariamente da vida do campo. Dentre os sujeitos que foram imbrincados nessa pesquisa, a única oriunda da zona rural era eu. $E$ uma das práticas de interior do sertão era as crianças irem à escola na "garupa da bicicleta do pai".
}

autoconfiança profissional, maior titulação e maior qualificação, maior será a consciência (ARROYO, 2011, p. 219), e nesse bojo, o processo de conscientização está posto nos mecanismos próprios da vida docente e de suas características, ou seja, eu poderia ou não assumir a identidade de uma raposa que não alcançava as uvas. Contudo, não aceitava esse papel para mim.

A identidade é um processo que necessita de tempo. Um tempo para identidades, para acomodar inovações, para assimilar mudanças, pois "a vida é o lugar da educação e a história de vida, o terreno no qual se constrói a formação" (NÓVOA, 1992, p.24), então o caminho da identidade docente se faz na trajetória educativa desde os primeiros momentos (da formação inicial, por exemplo). Isso resvala na condição de que assumir minha história e buscar estudá-la, academicamente, proporciona à construção formativa na qual fui/sou forjada professora.

Em um dado momento dessa linha do tempo de formação, capturo imagens sinestésicas, suscitadas ao relembrar a mudança da família para um povoado maior, com caraterísticas de distrito. Lá, meu pai assumiria a função de caseiro de uma chácara, de onde ainda sou capaz de sentir o cheiro doce das frutas, ao me remeter a esse espaço, cuja descrição apresenta uma grande variedade de árvores frutíferas, muitas caídas no chão de tão maduras, uma piscina enorme e um casarão maravilhoso, como nunca tinha visto na vida.

Fui estudar no prédio desta comunidade, eu e minha irmã mais velha, eu com 10 anos e ela com 11 anos. Fomos matriculadas na mesma série, após fazer um teste para ver se estávamos aptas a cursar a 3 a Série. Os livros eram ofertados pelo governo e os pais compravam o resto do material em meio a muitas dificuldades. Os alunos tinham que levar os temperos para o preparo da merenda e o entusiasmo era contagiante. Eu continuava acreditando que tinha alguma coisa muito boa para mim lá mais na frente.

Na chácara onde morávamos (morava minha família e a família do patrão de meu pai) tinha uma biblioteca linda que havia sido construída por meu pai, composta por uma estrutura arredondada, cheia de uma diversidade de livros incríveis. Éramos nós, as filhas do caseiro quem arrumávamos as estantes de livros nos dias de faxina para a esposa do patrão, uma mulher 
culta, muito elegante e professora. Ela sempre me dizia que aquela biblioteca era um espaço de grandes conhecimentos e me estimulava muito a ler, e foi nesse espaço onde passei boa parte de minha formação da pré-adolescência à idade adulta.

Entendo que o processo de conscientização, imerso no cenário educacional, perpassa pelo que é conhecido como saber experiencial familiar, que pode impulsionar $o$ sujeito (ou não) à tomada de consciência crítica do real. Através de histórias de como vivemos, de como fomos forjados, de histórias familiares, de natais e férias, é possível caminhar para a assunção da perspectiva do real papel de mudança social, afinal:

Ninguém nasce com
predeterminação daquilo
que vai ser. Quero dizer,
não acredito na frase
"nasceu professor, nasceu
médico", a gente se faz ou
não se faz, se cria como
médico, professor,
cozinheiro. Em certos
momentos da vida, a
gente começa a se
constituir nisso ou naquilo.
Embora,
indiscutivelmente,
também na infância, se
revele aos pais, aos
amigos e professores
certos gostos que
apontam para a direção de
uma profissão (FREIRE,
2004, p. 235).

Sobre isso, entendo ser relevante alinhavar a ideia de como, enquanto professores, em formação inicial e/ou em desenvolvimento profissional, situo a definição de identidade docente, na perspectiva de que:
[...] a identidade não é um dado adquirido, não é uma propriedade, não é um produto. A construção da identidade passa sempre por um processo complexo graças ao qual cada um se apropria do sentido da sua história pessoal e profissional (NÓVOA, 1992, p. 16).

E nesse caminho, eu respirava tudo; cada banho de piscina, cada reunião para estudo da bíblia, cada vez que era convidada para fazer uma comida diferente, as brincadeiras de escondeesconde, jogo imobiliário, a hora do conto de histórias, a paquera que começava a surgir, entre outros eventos naturais de ocorrências das minhas experiências de vida e formação, seguindo num rumo onde reafirmo que:

Toda práxis humana é
reveladora das
apropriações que os
indivíduos fazem dessas
relações e das próprias
estruturas sociais,
"interiorizando-as" e
voltando a traduzi-las em
estruturas psicológicas,
por meio de sua atividade
desestruturante-
reestruturante
(FERRAROTTI, 1988, p. 26).

O constante ir e vir no percurso da vida é uma atividade naturalmente formativa, que envolve estruturas sociais e as consequentes relações dentro dessas estruturas. Nesse caminho, após finalizar o Primário (como era chamado à época o Ensino Fundamental I), migrei do campo, da roça, para a cidade grande e com esse avanço, deparei-me com um processo de urbanização intenso, onde havia muita gente e a perspectiva de um futuro melhor era vislumbrada.

Paralelo a esta linha do tempo que indica minha transformação, "há um processo reflexivo entre o viver, contar, reviver e recontar de uma história de vida" (CLANDININ; CONNELY, 2011, p. 108), onde a temporalidade e a experiência são pontos centrais na construção dos textos de campo, onde estão registrados os meus momentos identitários no rol do desenvolvimento profissional docente.

Nesse percurso de inserção na cidade grande, eu ministrava reforço escolar ${ }^{7}$ para as filhas do proprietário da fazendo onde morava, e essa prática fazia com que eu estudasse mais ainda, e assim, constituísse a mim mesma como dadora de aula (ANGELIM, 2010, p. 84). Na verdade, eu já vinha me apropriando da docência desde o momento em que eu ajudava minha mãe nas aulas lá na Pedra Vermelha, na roça onde nasci, quando ela alfabetizava os adultos à noite

\footnotetext{
7 É a prática docente conhecida onde o sujeito ministra aulas conforme seus conhecimentos em determinadas disciplinas. É uma prática comum nas cidades, em especial, assumidas por licenciandos que atuam ministrando aulas particulares.
} 
em nossa casa. Era a configuração da minha formação inicial através das "experiências de campo que precedem o trabalho em cursos acadêmicos" (ZEICHNER, 1992, p. 297).

Apesar da docência se fazer presente no meu caminhar, mesmo que de forma inconsciente, eu nutria o sonho de ser Administradora de Empresas, pois achava bonito aqueles/aquelas executivos/executivas que via na TV, jornais ou revistas, mas como morava fora e não tinha transporte no horário do curso (era ofertado no turno noturno), tive que estudar Magistério no turno matutino. Meus pais não podiam pagar o colégio, eram quatro filhos, tinha que pagar transporte, material didático, farda e garantir a alimentação da família. Com uma renda de um salário mínimo, ficava muito complicado.

Então eu mesmo assumi a responsabilidade de buscar minha formação inicial mais qualificada (que requeria condições financeiras) e a convite da esposa do patrão, fui trabalhar numa escola infantil, cujo convite surgiu depois dela observar que em todas as manhãs depois que eu saia do Colégio eu ia para a escola, onde ela era diretora, ajudar as professoras da educação infantil, pois sempre nutri um amor muito grande por criança. Vivenciei uma significativa experiência neste momento: ser auxiliar da professora titular, o que representou, para meu processo formativo, um relevante momento charneira, pois tinha que ter perfil, compromisso, responsabilidade, competência e "botar a mão na massa", ou seja, compreendo que "as vivências de um professor, ao longo de sua trajetória profissional, estão contextualizadas historicamente na perspectiva de construção do tempo presente" (BASTOS, 2003, p. 167).

Analisava cada ensinamento, cada gesto profissional e orientações que era praticado em sala de aula. Em alguns momentos eu ficava um pouco assustada com o extremo de autoridade que a professora tratava as crianças, extremamente perfeccionista, não admitia o erro. Eu era orientada a não fazer intervenção nenhuma, afinal eu era apenas a ajudante e deveria me reservar a levar as crianças ao banheiro, arrumar as tarefas nas mochilas, cuidar delas na hora do recreio, ajudá-las na hora da escovação dos dentes e limpar a sala de aula com muito esmero.

Nessa direção formativa em que a busca memorial me traz à reflexão, ao apresentar esse contexto aos demais colegas com os quais trabalho, seja como docente, seja como coordenadora, como gestora, reitero a certeza que guardava, à época, em meus mais íntimos e desafiadores momentos de meditação, de que eu conhecia que professora seria, e hoje, me encontro com essa construção iniciada há décadas atrás, quando valorizava o perfil professoral bem organizada e responsável, mas associado ao comportamento doce e paciente.

Por considerar que não me constituo sozinha num processo ampliado de formação, nesse artigo compreendo que estar envolvida com colegas que atuam com o mesmo objeto de trabalho, estudos e pesquisas - a EJA, me permite, ao imergir nos memoriais desses colegas, tomá-los como meus textos de campo, a fim de produzir meu texto de pesquisa onde os diálogos entre os colegas, os teóricos e eu, poderão constituir uma triangulação válida de compreensão das influências no meu processo de formação e desenvolvimento profissional docente.

É também com as leituras dos memoriais e do que eles me revelam, que busco estabelecer relações com o meu singular, a fim de me situar no processo de formação e reconhecer que a partir deste dá-se a percepção identitária no percurso do desenvolvimento profissional docente.

\section{DIALOGANDO INDIRETAMENTE ATRAVÉS DOS MEMORIAIS NA BUSCA DO RECONHECIMENTO IDENTITÁRIO DOCENTE}

Nesse discorrer das memórias/recordações, sustentado, também, nas leituras dos memoriais dos colegas professores, remeto-me a um dos sujeitos investigados, que aqui chamarei de Alfa, quando traz um relato de desabafo sobre a atitude docente no cuidar do outro:

[...] um descaso com os alunos, a falta de compreensão, de apoio, de sensibilidade, motivação, o que não acontece só com crianças ou alunos do Fundamental, mas com pessoas adultas, graduadas e até especialistas de outras áreas, que é o meu caso. Isso talvez explique o motivo do número de alunos evadidos (ALFA, 
2018, Q.1).

É lítico considerar como ponto de referência formativa, proporcionado pela experiência da observação docente, que em processo de desenvolvimento profissional, "se você passa por uma experiência, a experiência passa por você, e aí, nesta mútua 'passagem', fica um conhecimento que a experiência deixou" (FREIRE, 2005, p. 143), isto é, a prática do professor em formação contínua o coloca em condição de um aluno com perfil formativo diferenciado (porque já é professor na prática cotidiana), e o faz reconhecer que:

[...] a prática docente $\mathrm{e}$ prática discente - porque, no fundo, você não pode separar o ensinar do aprender; é impossível compreender a prática do ensinante sem compreender a prática do aprendiz - são momentos de um único processo: o processo de produção do conhecimento em nível sistemático.

A utilização dos memoriais como instrumentos propiciadores de reflexão quanto ao meu percurso formativo, me leva a defender essa relação necessária e suficiente [da leitura do outro, de mim mesma, e do outro em mim], de forma a considerar que "os textos permitem que os professores em formação estejam em contato com seu próprio desenvolvimento", proporcionando, através desse contato aumento de sua autoconfiança, condição de "verem-se a si próprios como produtores de conhecimento legitimado" (BULLOUGH, apud MARCELO GARCIA, 1997, p. 497), o que fortalece na consolidação de seus valores frente ao despertamento da prática reflexiva docente.

O sujeito Alfa dialoga na linha comum ao que propõe Zabalza (2004), pois entende que o tratamento dos docentes para com os alunosprofessores, no curso de formação continuada a que se submeteu, criou um eco reflexivo, advertindo-o sobre sua prática pedagógica, já que essas reflexões são elementos das memórias que constam no memorial, que se constitui como um espaço narrativo dos pensamentos, e pode constituir-se num instrumento que pode favorecer a coleta de informações sobre dificuldades, problemas, expectativas e motivações.

O olhar dos docentes para os discentes em formação, em alguns casos, sugere desconsiderar a estrutura/conjuntura social na qual estamos inseridos enquanto sujeitos sociais, e que, nessa mesma estrutura, muitos dos estudantes são trabalhadores em formação. Portanto, ao me ver atuar como ajudante escolar, compreendia que não mantinha condições suficientes para investir no meu processo de formação da forma como desejava. Essa situação me levou a assumir o papel de autônoma e, com a herança do seio familiar feminino, passei então, a produzir "panos de prato", jogos de mesa e demais artefatos da casa, para vender e assim, contribuir com um acréscimo da renda mínima que mantinha como auxiliar de sala de aula.

Assim, como os sujeitos Delta e Gama, o desejo de ser professora e ter uma formação de atuação humanizadora, como pensávamos, nos fez buscar apoios diversos na sociedade onde vivíamos. Busquei apoio junto à direção de um educandário que formava professores e solicitei auxílio à mesma a fim de obter uma bolsa de estudos. Fui contemplada com metade da mensalidade, com uma exigência: não obter notas "vermelhas" 8 , o que contemporaneamente, me faz revisitar o passado, a fim de desvelar como o processo de formação se compunha. Nesse norte, a partir da perspectivação da aquisição de saberes próprios da docência, entendo que:

O docente raramente atua sozinho. Ele se encontra em interação com outras pessoas, a começar pelos alunos. A atividade docente não é exercida sobre um objeto, sobre um fenômeno a ser conhecido ou uma obra a ser produzida. Ela é realizada concretamente numa rede de interações com outras pessoas, num contexto onde o elemento humano é determinante e dominante e onde estão presentes símbolos, valores, sentimentos, atitudes, que são passíveis de interpretação e

\footnotetext{
${ }^{8}$ Historicamente falando, notas abaixo da média eram chamadas de notas vermelhas por serem apresentadas no boletim escolar nas próprias avaliações sob a cor vermelha.
} 
decisão, interpretação e decisão que possuem, geralmente, um caráter de urgência (TARDIF, 2007, p. 49-50).

Uma emergente perspectiva acadêmica de produção nos permite considerar que tratar de história vivida em tempo/espaço real - por sujeitos, homens e mulheres reais, com todas as contradições que a condição humana impõe, mas também com toda boniteza que essa mesma condição possibilita, fundamentada na certeza da incompletude, do inacabamento (FREIRE, 1996), é que nos dá a condição de mudar, transformarmo-nos, e também transformar o que está ao nosso redor, e ao fazê-lo, surpreender, encantar, emocionar. Assim, contamos com nossos conhecimentos, experiências acumuladas, criatividade, intuição, reflexão, para transformar limites em possibilidades, frustrações em novas aprendizagens.

O professor encontra-se num cenário em que é relevante refletir sobre si, como profissional e como pessoa, fatores que são de uma dimensão inseparável. Os memoriais formativos constituem essa proposta multidimensional em que possibilitam o diálogo entre os contextos e sujeitos, ao fazerem referências às experiências e dificuldades de seu percurso formativo.

Ao se remeterem ao passado, no período em que estudavam nos anos iniciais, destacam que:

Quando eu tinha quatro anos, nos mudamos para Senhor do Bonfim. Meu pai sempre animado com muitas expectativas para o nosso futuro trabalhou para nos dar o melhor. Estudei o primário em escola pública, pois tínhamos acabado de chegar e. quando ingressei na escola, minha família estava arrumando a vida profissionalmente.

Recordo-me com muitas saudades os momentos que tive na Escola Estadual $\mathrm{X}$, amava os professores, a merendeira, o porteiro era um amor de pessoa (ALFA, 2018, Mem.).

Na minha infância não freqüentei a pré-escola, hoje Educação Infantil, mas morava em frente uma escola, meu pai era assalariado e nós ficávamos esperando a hora da merenda. Como a merendeira era muito "camarada", sempre nos dava merenda, tanto a mim como aos meus irmãos. Ficávamos esperando a merende e ouvia a professora ensinando o "b $+a=b a "$ aos seus alunos, enquanto ficávamos na vontade de entrar na sala, mas como não era matriculada, não era permitido o acesso (BETA, 2018, Mem.).

Acompanhava minha mãe e ficava numa sala e noutra, rabiscando e folheando os livros da escola, pois naquela época, trabalhavam como professoras, minha mãe, minha avó e duas tias. Era uma Fartura! Todas queriam me alfabetizar! [...] Minha história de alfabetização me faz entrar numa máquina do tempo, rica de carinho, prazer e aconchego [...] lembro com saudade da figura materna tão amada e com a graça de Deus bem presente em nossas vidas, a professora $M$ (minha mãe), que me apresentou no mundo mágico da leitura e escrita. Não posso deixar de mencionar a contribuição da professora leiga (a mais doutora que já conheci); a professora A (avó paterna). Foram estas, as mais belas mulheres que plantaram as primeiras sementinhas do conhecimento no meu jardim, que começava a desabrochar para o mundo rico da leitura.( memorial - Delta). 
A polifonia torna-se uma marca constante neste texto, uma vez que são as várias vozes convergindo num constructo coletivo que ampara as caraterísticas individuais da formação docente. É o passado, o presente e o futuro se misturando no agora. Eu, Alfa, Beta e Delta, no enfrentamento às dificuldades e contemplação das alegrias na infância em busca de um lugar ao sol, através dos estudos e com o apoio da família. As impossibilidades financeira e cultural da família encontram uma relação nas falas dos sujeitos Alfa e Beta quando externam: "minha família estava arrumando a vida profissional", "[...] meu pai era assalariado [...] só ficava na vontade de entrar na sala, mas não era matriculada", respectivamente.

Diante disso, percebo que não me conheço o tempo todo sozinha e não me constituo sozinha; preciso do outro para me ver, para me conhecer, ou seja, o eu só existe a partir do diálogo com outros eus e precisa dos outros para construir seu próprio eu (BAKHTIN, 1995).

Continuo retroalimentando a minha caminhada diante das experiências vivenciadas por mim e pelos colegas professores, e, assim me percebo professora diante do cotidiano e das diferentes instâncias nas quais tenho interagido, nas diversas interlocuções que tenho feito, nas múltiplas relações estabelecidas, ao longo desta jornada, na perseguição teórico-epistemológica que tenta "compreender como evolui a pessoa que é o professor, ao longo da idade e com a profissão, na relação com outros intervenientes diretos do ato educativo, na relação com o saber, na relação consigo mesmo" (CAVACO, 1995 p. 159).

Ao tomar conhecimento das histórias de vida dos colegas professores, através de seus memoriais, desestruturo-me quanto ao meu olhar crítico sobre a atuação do outro, suas limitações e possibilidades. É como se eu fosse convidada a olhar para meus alunos, ou para o outro, de forma mais cautelosa e numa perspectiva da Pedagogia da amorosidade como nos convida Paulo Freire. Neste momento, dialogo comigo mesmo.

São histórias que se repetem ou se distanciam, mas que vão dando um tom algumas vezes semelhantes, outras vezes, com nuances diferenciadas, singulares. Porém, são construídas com atitudes simples, extraídas de dentro da organização da vida e relacionam um conceito de formação docente que perpassa pelo argumento de que "é tomado não só como uma atividade de aprendizagem situada em tempos e espaços limitados e precisos, mas também como a ação vital de construção de si próprio" (MOITA, 2013, p.114), e cujas experiências exaradas nos memoriais me permite assinalar, que no processo de formação "a relação entre os vários polos de identificação é fundamental" (MOITA, 2013, p. 114).

Portanto, sobre o tempo e o espaço e as relações de formação, desde as alegrias e tristezas, perpassando por vitórias e derrotas, é preciso considerar os espaços experienciais como necessários à identidade pessoal e profissional. Nessa direção, dois contextos convergentes, mas significativamente formativos, merecem destaque, dos memoriais:

Até hoje trago na lembrança o dia em que a professora me chamou para ler, comecei a leitura e no meio do texto tinha a palavra CÓLERA, e eu só pronunciava COLERA, ela explicava que 'colera' 9 era de colocar em cachorro, mas não me dizia o significado de cólera, então eu não conseguia dizer a palavra. Lembrome que fiquei em pé por mais de trinta minutos e todos os colegas me olhando, eu quase não consegui voltar para o meu lugar de tanta vergonha. Hoje eu percebi o quanto isso me afetou, pois tenho medo quando vou ler em público. Sei que a atitude da professora deveria ter sido outra, talvez se ela tivesse explicado o significado das duas palavras, dito que mais na frente nós iríamos conhecer melhor o assunto sobre acentuação, hoje eu não tivesse esse medo terrível. Percebo o erro que a minha professora cometeu; tento não fazer o mesmo, gosto de explicar aos meus alunos e tirar todas as dúvidas para que eles não

\footnotetext{
${ }^{9} \mathrm{O}$ que era entendido era o termo "coleira" como um
} colar que envolve o pescoço do cachorro ou gato. 
venham sofrer o que hoje sofro (BETA, 2018, Mem.).

O Colégio de Padres foi onde eu cursei a 5a Série, o diretor era o irmão $A L$, eu morria de medo dele, era super carrasco, gritava com todos... [...] Após a conclusão do segundo grau, fui aprovada numa seleção de PROESP - no curso de Química, mas não conclui o curso, pois um fato humilhante me fez desistir: ao apresentar um seminário, em equipe, eu e todos os componentes fomos ridicularizados quando apresentávamos. A professora não gostou e diante da turma nos humilhou, chamando atenção de forma grosseira e fria. Naquele momento, me senti a pior pessoa, incapaz, derrotada. Retirei-me da sala depois de discutir e defender a mim e a todos os colegas que também passaram e sentiram o que eu senti. Procurei meus direitos frente a instituição, mas não tive mais condições psicológicas de continuar o curso. Desisti. Diante do ocorrido, passei muito tempo sentindo enorme dificuldade de me expressar diante de uma apresentação em público. Mas, continuei na luta em busca de aprimorar e enriquecer meus conhecimentos. "Hoje, graças a Deus superei essa problemática dentro de mim" (ALFA, 2018, Mem.).

Como é possível verificar, mais do que pelo relato em si, as narrativas tornam-se relevantes pelo processo reflexivo que desencadeiam no narrador e no ouvinte, daí seu potencial formativo (CUNHA, 1998). Neste contexto, expressado pelos sujeitos acima, a escola se apresentava carregada de exclusão, pois tanto Alfa quanto Beta, tinham medo e vergonha de errar. Diante do exposto, a escola ainda é vista em uma concepção hegemônica de verdade única e absoluta.

Os sujeitos Alfa e Beta possibilitam, com suas experiências, um diálogo onde a rememoração é um processo seletivo que envolve enfocar algumas situações e desfocalizar outras (KENSKI, 1997), dada a condição de que esse diálogo está profundamente vinculado a aspectos emocionais e conjunturais dos próprios sujeitos. Logo, esse movimento de contar-se, ouvir-se por meio de vivências rememoradas, propicia reflexão e autoconhecimento sobre a maneira particular que cada um percebe e compreende sua forma de ser e estar na prática educativa, possibilitando aos sujeitos transformála quando a percebem em desacordo com suas formas de compreensão atual por serem frutos de valores e pressupostos claramente assimilados num processo de formação, incidental, no geral, irrefletido.

No excerto de Alfa, mesmo diante da experiência negativa frente à professora na Universidade, há a decisão de persistir, quando diz que "[...] continuei na luta em busca de aprimorar e enriquecer meus conhecimentos", o que para Beta gera uma autorreflexão quanto a sua prática pedagógica em sala de aula, enfrentada como resistência à desistência experimentada outrora e conforme ela mesmo assevera "[...] tento não fazer o mesmo, gosto de explicar aos meus alunos e tentar tirar as dúvidas para que eles não venham sofrer o que sofri e ecoa em minhas recordações."

Ambos os contextos fortalecem a afirmação de que o processo de desenvolvimento profissional docente, "não inclui apenas a própria experiência, mas, em grande parte, a experiência alheia" (BENJAMIM, 1994, p. 221), ratificando o que tenho defendido quanto ao fato de minha constituição docente ser consequência de uma identidade multirreferencial $^{10}$.

Outrossim, compreendo que nós, enquanto sujeitos autores e atores em educação, temos consciência de que as iniciativas em torno da educação constituem o elo entre si e o mundo

\footnotetext{
10 Quando abordo o conceito, eu o uso na perspectiva de compreensão de uma constituição não-singular na qual, a perspectiva multirreferencial propõe, por sua vez, abordar as questões anteriores tendo como objetivo estabelecer um novo "olhar" sobre o "humano", mais plural, a partir da conjugação de várias correntes teóricas, o que se desdobra em nova perspectiva epistemológica na construção do conhecimento sobre os fenômenos sociais, principalmente os educativos (MARTINS, 2000, p. 86).
} 
em todos os aspectos: social, afetivo, familiar, econômico, etc. É perceptível nas narrativas um forte sentimento de crescimento, de evolução, e assim, o auto movimento educacional resvala na capacidade de exercermos com autonomia a nossa atividade, pelo sentimento de que controlamos o nosso trabalho (NÓVOA, 1995b) e os anseios de formação podem produzir saberes experienciais que configuram um perfil identitário docente desejado.

$\mathrm{Na}$ perspectiva consciente do anseio de formação profissional, tomando a temporalidade associada à atitude frente à autonomia profissional, fui, juntamente com meus colegas de trabalho construindo um caminho, onde a atuação enquanto "dadora de aula" impulsionoume a ser e estar na profissão, já antes do acesso à Universidade. Assim, as decisões acerca do ofício de mestre, foram arroladas, paulatinamente, no final da adolescência, quando chegamos ao segundo grau $^{11}$ e o finalizamos com o título de professora.

$$
\begin{aligned}
& \text { Conclui o curso de } \\
& \text { magistério (ensino médio) } \\
& \text { em 1985, no ano seguinte } \\
& \text { comecei a trabalhar com } \\
& \text { reforço escolar para as } \\
& \text { séries iniciais (DELTA, } \\
& \text { Mem.). } \\
& \text { [...] Fiz o ensino médio no } \\
& \text { Colégio de Administração, } \\
& \text { a noite, só para namorar, } \\
& \text { pois papai era muito } \\
& \text { rígido. Conclui o curso de } \\
& \text { Técnica em Administração. } \\
& \text { Porém este não era o meu } \\
& \text { desejo. Filha de professora } \\
& \text { tinha sonho de seguir a } \\
& \text { mesma profissão. } \\
& \text { Admirava a postura, a } \\
& \text { forma como minha } \\
& \text { conduzia os trabalhos } \\
& \text { pedagógicos. Recordo-me } \\
& \text { as várias vezes que fui à } \\
& \text { escola que ela lecionava e } \\
& \text { assistia às aulas; sempre } \\
& \text { dinâmica, acolhedora, com } \\
& \text { muitas brincadeiras... Os } \\
& \text { alunos a amava. [...] } \\
& \text { Mesmo não tendo feito } \\
& \text { magistério, fui contratada } \\
& \text { para atuar como regente } \\
& \text { auxiliar em uma escola de } \\
& \text { educação infantil. Foi } \\
& \text { minha primeira }
\end{aligned}
$$

\footnotetext{
${ }^{11}$ É o termo da época equivalente ao Ensino Médio atualmente.
}

experiência profissional (ALFA, 2018, Mem.).

[...] Foi quando minha mãe resolveu que eu tinha que ser professora, que era a única profissão para mulher, vai estudar no colégio de Freiras. Pior ano da minha vida escolar, não me adaptei em nada, me sentia marginalizada em sala de aula, resolvi desistir de ano, pois por mais que eu estudasse não conseguia tirar boas notas. Eu tinha uma opinião negativa formada sobre a referida escola. Desisti. No ano seguinte foi implantado Magistério num Colégio Estadual; como minha tia era diretora, fez minha matricula e voltei a estudar para ser professora. [...] Me identifiquei muito. Tudo foi maravilhoso. Fiz meu estágio com a professora que ouvira as aulas na infância do $B+A=B A$. Só comecei a lecionar depois que passei no concurso de professora (BETA, 2018, Mem.).

Compreendo, a partir dos excertos apresentados, a existência de várias similaridades formativas, no entanto uma delas faz referência à influência materna por serem professoras. Essa realidade, de terem em casa professoras leigas ou formadas, como também é o meu caso, traz à tona a não linearidade do tempo; e a evidência disso é a intensidade das experiências vividas que nortearam as escolhas de cada indivíduo (BENJAMIM, 1995).

A formação profissional ganha força relevante frente ao exercício da profissão professor uma vez que as influências pessoais e profissionais produzem mudanças políticas, sociais e econômicas e acentuam cada vez mais rapidamente, a certeza de que "ao longo de sua trajetória, o professor é, em todos os momentos, - resultado de seu percurso pessoal e profissional" (GUEDES, 2006, p. 151). Assente nessa condição, o ingresso na Universidade surge, através da busca incessante de conhecimento e 
consequente aperfeiçoamento, de forma a garantir embasamento dos saberes e das práticas docentes num contexto educacional onde se apresenta o paradigma da sociedade do conhecimento.

Ongresso na
Universidade foi o
primeiro passo para
grandes conquistas. Esse
período foi muito intenso,
certamente todos os
trabalhos realizados na
Universidade, também os
promovidos fora dela, me
possibilitaram
enriquecimento incrível,
promovendo exercícios de
reflexão e análise da
formação humana e
profissional. A partir daí,
senti que, com tudo isso,
minha prática pedagógica
se renova e se revigora
(ALFA, Mem.).
[...] no final de 1999 surgiu
uma oportunidade para os
professores municipais,
uma seleção UNEB 2000,
muito criticada pelos
alunos da graduação
normal, mas que mudou a
vida de muitos professores
fiz minha inscrição e fui
selecionada entre os
quarentas. Começo da
graduação, muitos
trabalhos, pouco tempo,
dois filhos totalmente
dependente, muitas
lágrimas, mais também
muitas alegrias
conquistas (BETA, 2018,
Mem.).

A necessidade de escrever sobre os processos de formação e desenvolvimento profissional docente, me levam a caminhar para uma ressignificação do processo de identidade docente e, para isso, propus retomar o caminhar da vida profissional de professores envolvidos na EJA, incluindo-me como sujeito em constante formação, mas associada à outros professores que, ao produzirem seus memoriais formativos permitiram a mim e a muitos outros, configurar o caminho das escolhas autos significativas que "resultam de relações complexas que se tecem entre a definição de si e a percepção interior, entre o objetivo e o subjetivo, entre o eu e o outro, entre o social e o pessoal" (MOITA, 2013, p. 115).

Assim, em todo esse percurso, entre as idas e vindas, me vi inserida, no campo investigativo, quando vivenciei, inferindo e produzindo, histórias advindas das minhas experiências e das experiências dos colegas professores, pude contá-las, recontá-las, revivêlas, em muitos momentos modificando situações éticas e morais, a fim de atribuir seguridade e legitimidade com discrição e justiça. Deste modo, também se faz o caminhar profissional, que resgata o passado vivido costurando ao presente com as projeções que esse passado produziu, para enfim, elaborar um futuro tecido a várias mãos e cabeças, considerando que a consolidação da confiança é um processo que emerge da partilha da história de vida e formação do sujeito.

Portanto, é possível sustentar nossa relação acadêmico-formativa, na perspectiva de que a experiência deve levar o sujeito docente à compreensão de que "a conscientização é isto: tomar posse da realidade; por esta razão, e por causa da radicação utópica que a informa, é um afastamento da realidade" (FREIRE, 1979, p.15) que sugere o desenvolvimento da tomada de consciência para então produzir ações.

Contar as experiências vividas em meu processo formativo corrobora com a afirmação de que a experiência é o "alicerce" para a transformação social, dado que no processo de desenvolvimento profissional docente, a cognoscência é preponderantemente produzida a partir da tomada de consciência e, nesse caminho as histórias entrelaçadas produzem experiências que intencionam a ampliação do olhar em torno das histórias de vida que podem transformar distintos contextos de formação docente.

\section{CONSIDERAÇÕES FINAIS}

Este artigo, produto de uma macro pesquisa que estuda formação e desenvolvimento profissional de professores, antes de buscar responder a uma inquietação especial, carrega a missão de proporcionar intencionalidades reflexivas no mundo acadêmico, tendo como objeto de estudo o processo de identidade docente. Não havia, para mim, melhor contexto de conduzir essa investigação, que não fosse a Pesquisa Narrativa que, para além de me proporcionar uma formação docente criteriosa a partir da escrita de 
si, desvelou múltiplas reverberações das minhas experiências de vida e formação.

Ao resgatar um percurso formativo que me constitui como sujeito/atriz/autora de minha própria formação pessoal e profissional, me utilizo de fatos, crenças, histórias e mosaicos que se apresentam a mim, enquanto produtora de conhecimento docente, na rememoração das memórias/recordações que compõem minha linha de vida, caminhando até os dias atuais.

Os elementos experiência e temporalidade estão contidos nos textos de pesquisa, revelados na forma de memoriais e diários de campo, e ao tempo em que são postos, dão vida à pesquisa e à formação docente, ao contar e recontar as histórias, ressignificando-as, no intuito de formar e transformar os sujeitos, pois a pesquisa narrativa enquanto método é uma forma de entender a experiência, considerando que "experiência acontece narrativamente. Pesquisa Narrativa é uma forma de experiência narrativa. Portanto, experiência educacional deveria ser estudada narrativamente" (CLANDININ; CONNELY, 2011 p. 49).

Os teóricos são convidados a sentar-se à mesa da compreensão formativa, para juntos às memórias apresentadas destacar o lugar almejado na investigação da formação docente que pretende este texto, sem a intenção de esgotá-lo por si mesmo. No entanto, para a limitação do momento apresentado, fez-se necessário destacar que a opção pelo Magistério já me caracterizava desde cedo, bem como aos outros sujeitos que contribuíram com esta investigação. Os perfis apresentados lançam mão da cultura do auxiliar de conhecimento, ou seja, os sujeitos envolvidos, através de suas memórias, apontam a docência como trajetória de vida e formação, oriundas, dentre outros fatores, do desejo de construção de um mundo melhor através do ato de ensinar.

Entrecortando as histórias de minha vida e as histórias dos colegas professores, ratifico, academicamente, que "Pesquisa Narrativa são histórias vividas e contadas" (CLANDININ; CONNELY, 2011 p. 51). Portanto, nesse artigo, ao perpassar, num primeiro momento, pela justificativa da escrita de si, prossegue tratando do meu percurso de vida e por fim, dialoga com as memórias/recordações contidas nos memoriais dos colegas professores, a partir de onde eu faço inferências da minha ascensão à profissão docente.
Pensar na formação do professor como um processo, cujo início se situa muito antes do ingresso nos cursos de habilitação específica, embasa o argumento de que é nas experiências de vida que a formação se apresenta e uma das formas de análises dessa experiência está no fato de que "as pessoas vivem histórias e no contar dessas histórias se reafirmam" (CLANDININ; CONNELY, 2011 p. 27). Então,

$$
\begin{aligned}
& \text { [...] a história de vida é } \\
& \text { outra maneira de } \\
& \text { considerar a educação. Já } \\
& \text { não se trata de aproximar } \\
& \text { a educação da vida, como } \\
& \text { na perspectiva da } \\
& \text { educação nova ou da } \\
& \text { pedagogia ativa, mas de } \\
& \text { considerar a vida como o } \\
& \text { espaço de formação. A } \\
& \text { história de vida passa pela } \\
& \text { família. É marcada pela } \\
& \text { escola. Orienta-se para } \\
& \text { uma formação } \\
& \text { profissional, e em } \\
& \text { consequência beneficia de } \\
& \text { tempos de formação } \\
& \text { contínua. A educação é } \\
& \text { assim feita de momentos } \\
& \text { que só adquirem o seu } \\
& \text { sentido na história de uma } \\
& \text { vida. (DOMINICÉ, 1988b, } \\
& \text { p. 140). }
\end{aligned}
$$

Julgo que as inter-relações analisadas a partir do que constituiu meu processo formativo foi direcionado de forma dinâmica, complexa e pertinente à intersubjetividade plural como alicerce dialógico entre $\mathrm{mim}$ e os colegas professores. As teorias do conhecimento na perspectiva da Pesquisa Narrativa validam a constante construção ontológica que afirma que a história é tempo de possibilidades e não de determinismo, que o futuro é problemático e não inexorável (FREIRE, 1996), pois no processo de contar e recontar as histórias de nossas vidas, desde a infância à época contemporânea, "sinalizam que ser humano é também criar as histórias que simbolizam a nossa compreensão das coisas da vida" (JOSSO, 2010, p. 40).

Contar com a prática investigativa da escrita de si é, num certo momento, uma volta ao início de tudo; porém, acredito que as articulações dos momentos vividos, experienciados e narrados, interconectados com as histórias de outras pessoas, podem proporcionar a compreensão de que "o outro 
está sempre presente na constituição estética do sujeito, como uma dobra da relação consigo mesmo" (SCHOLZE, 2007, p. 89), e assim, entender a dinâmica de evolução no percurso, deixando marcas formadoras em nossas vidas, que levam o leitor a uma prática constante de ação-reflexão-ação de sua atuação profissional.

A imersão nos textos de campo que produziram textos de pesquisa me fez adentrar a um universo que precisa ser contemplado e aproveitado, pois esses textos estão compostos de experiências que manifestam sabedoria e conhecimento de vida, que possibilitam momentos de aprendizagem significativa e de reconhecimento dos processos identitários produzidos dentro e fora da sala de aula.

A dinâmica de visualizar os caminhos por onde os colegas professores trilharam permite identificar a relevância das vozes de tantos sujeitos que assim como eu, estão constituindo seu processo individual que ecoa nos distintos processos pessoais e profissionais de colegas e alunos. Com isso, amplio esse olhar ao me proporcionar vivenciar a Academia, e nesse meio constituir-me junto ao meu orientador, por exemplo, numa perspectiva de autenticidade investigativa cuja escuta sensível e ativa me faz certificar-me que formar é formar-se no reconhecimento de que a pesquisa é um dos princípios dinamizadores da formação inicial e continuada do professor e a prática professoral o ofício docente emerge, então, como princípio educativo, onde a epistemologia da prática se institui cada vez mais nos projetos formativos.

Por fim, a efetivação deste artigo, me lança na busca pelo fortalecimento, consolidação e consequente partilha de minhas/nossas experiências de vida e formação, onde e pelas quais, direciono o constante desenvolvimento profissional docente, a partir do qual, fundamentado na escrita de si, suscita a defesa de que as histórias que vivo, ao serem contadas, têm o poder de educar a mim e as pessoas que as leem e nela se reconhecem.

\section{REFERÊNCIAS}

ALFA. Entrevista I. Entrevistadores: Edvone da Silva Souza, Jose Aurimar dos Santos Angelim. Senhor do Bonfim-BA, 2018. Entrevista concedida para fins de pesquisa.

\section{ANGELIM, J. A. S. Formação de professores de}

Matemática: um estudo sobre os aspectos formativos de docência dos licenciandos em
Matemática da UFPA. 2010. 156f. Dissertação (Mestrado - Educação em Ciências Matemáticas), Universidade Federal do Pará, Belém-PA, 2010.

ARROYO, M. G. Ofício de Mestre: imagens e auto-imagens. 13. ed. Petrópolis, RJ. Vozes, 2011.

BASTOS, M. H. C. Memórias de professoras: reflexões sobre uma proposta. In: MIGNOT, A. C. V.; CUNHA, M. T. S. (Orgs.). Práticas de memória docente. São Paulo: Cortez, 2003. p. 167-183.

BAKHTIN, M. Língua, fala e enunciação. In: BAKHTIN, Mikhail. Marxismo e filosofia da linguagem. Tradução de Michel Lahud e Yara F. Vieira). São Paulo: Editora 34, 1995, p. 93-113, v.13.

BENJAMIN, W. O surrealismo: o último instantâneo da inteligência européia. In: BENJAMIN, W. Magia e Técnica, Arte e Política: ensaios sobre literatura e história da cultura. Tradução de Sergio Paulo Rouanet. 7. Ed. São Paulo: Brasiliense, 1994, p. 21-35. (Obras escolhidas v. 1).

BETA. Entrevista II. Entrevistadores: Edvone da Silva Souza, Jose Aurimar dos Santos Angelim. Senhor do Bonfim-BA, 2018. Entrevista concedida para fins de pesquisa .

CAVACO, M. H. Ofício do professor: o tempo e as mudanças. In: NÓVOA, A. (Org.). Profissão professor, 2. ed. Porto: Porto, 1995, p. 155-191, v.2.

CHAVES, Silvia Nogueira. Reencantar a ciência, reinventar a docência. São Paulo: Editora da Física, 2013.

CLANDININ, D. J.; CONELLY, F. M. Pesquisa narrativa: experiências e história na pesquisa qualitativa. Tradução de Grupo de Pesquisa Narrativa e Educação de Professores ILEEL/UFU. Uberlândia: EDUFU, 2011.

CUNHA, M. I. Aportes Teóricos e Reflexões da Prática: A Emergente Reconfiguração dos Currículos Universitários. In: MASETTO, M. T. (org.). Docência na Universidade. Campinas (SP): Papirus; 1997.

DOMINICÉ, P. O que a vida lhes ensinou. In: NÓVOA, A.; FINGER, M. (Orgs.). 0 método 
(auto)biográfico e a formação. Lisboa: Ministério da Saúde, Departamento de Recursos Humanos da Saúde/Centro de Formação e Aperfeiçoamento Profissional, 1988.

FERRAROTTI, F. Sobre a autonomia do método biográfico. In: NÓVOA, A; FINGER, M. (Orgs.). 0 método (auto)biográfico e a formação. Lisboa: Ministério da Saúde. Depart. de Recursos Humanos da Saúde/Centro de Formação e Aperfeiçoamento Profissional, 1988.

FREIRE, P. Pedagogia da tolerância. São Paulo: Editora UNESP, 2004.

FREIRE, P. Pedagogia da autonomia: saberes necessários à prática docente. São Paulo: Paz e Terra, p. 25, 1996.

FREIRE, P. Conscientização: teoria e prática da libertação, uma introdução ao pensamento de Paulo Freire. São Paulo: Cortez e Moraes, 1979.

GOODSON, I. F. Dar a voz ao professor: as histórias de vida dos professores e o seu desenvolvimento profissional. In: NÓVOA, A. (Org.). Vidas de professores. Portugal: Porto Editora, 2013, p. 63-78.

GUEDES, N. C. O(s) saber(es) e o(s) fazer(es) do professor formador: reflexões sobre a prática docente. 2006. 200f. Tese (Doutorado em Educação) - Universidade Federal do Rio Grande do Norte, Natal, 2006.

JOSSO, M.C. Experiências de vida e formação. Natal: EDUFRN; São Paulo: Paulus, 2010.

KENSKI, Vani. Memórias e formação de professores: interfaces com as novas tecnologias de comunicação. In: CATANI et al. (Org.) Docência, memória e gênero: estudos sobre formação. São Paulo: Escrituras Editora, 1997.

LABORIT, H. L'espirit du grenier. Paris: Grasset, 1992.

LARROSA, J. Notas sobre a experiência e o saber da experiência. Revista Brasileira de Educação, Rio de Janeiro, n. 19, p. 20-28, jan./abr. 2002.

LEITÃO, C. F. Buscando caminhos nos processos de formação/autoformação. Revista Brasileira de Educação, Rio de Janeiro, p. 25-39, 2000.
MARCELO GARCIA, C. Pesquisa sobre a formação de professores. Revista Brasileira de Educação, Rio de Janeiro, n. 9, p. 31-75, 1997.

MARTINS, J. B. Contribuições epistemológicas da abordagem multirreferencial para a compreensão dos fenômenos educacionais. Revista Brasileira de Educação, Rio de Janeiro, p. 85-94, 2000.

MOITA, M.C. Percursos de Formação de Transformação. In: Nóvoa, A. Vidas de Professores. Porto: Porto Editora, 2013. p. 111-132.

NÓVOA, A. Formação de professores e profissão docente. In: NÓVOA, Antônio (Org.). Os professores e a profissão. Lisboa: Dom Quixote, 1992. p.15-33.

NÓVOA, A. Os professores e as histórias da sua vida. In: NÓVOA, A. (Org.). Vidas de professores. 2. ed. Porto: Porto Editora, 1995a.

NÓVOA, A. Os professores e as histórias da sua vida. In: NÓVOA, A. (Org.). Vidas de professores. Portugal: Porto Editora, 1995b.

PESSOA, F. O eu profundo e os outros eus. Rio de Janeiro: Nova Fronteira, 1980.

PIMENTA, C. A. Atitude de doentes com dor crônica frente à dor. Tese de livre-docência. Escola de Enfermagem. São Paulo: Universidade de São Paulo, 1999.

ROSA, J. G. Grande Sertão: Veredas. 20. ed. Rio de Janeiro, Nova Fronteira, 2003.

SANTOS, B. S. Um discurso sobre as ciências. Porto: Ed. Afrontamento, 2001.

SCHOLZE, L. Narrativas de si e a estética da existência. Em Aberto, v. 21, n. 77, p. 61-72, jun. 2007.

SCOZ, B. J. L. Identidade e Subjetividade de professores: sentidos do aprender e do ensinar. Petrópolis, RJ: Vozes, 2011.

TARDIFF, M. Saberes docentes e formação profissional. 8. ed. Petrópolis, RJ: Vozes, 2007.

VYGOTSKY, L. Pensamento e Linguagem. São Paulo: Martins Fontes, 1991. 
ZABALZA, Miguel A. 0 ensino universitário. Porto Alegre: Artmed, 2004.

ZEICHNER, K. M. A formação reflexiva de professores: Ideias e práticas. Lisboa: Educa Professor, 1992.

Recebido para publicação em: 24/02/2018

Revisado em: 03/09/2018

Aceito em: 28/10/2018 